\title{
HR - Corporate Governance Nexus: Implications for the Development of Nigeria's Banking Sector Services
}

\author{
${ }^{1}$ O. R. Shabi, ${ }^{2}$ I. A. O. Bakare, ${ }^{3}$ A. C. Edun \\ ${ }^{I}$ Department of Industrial Relations and Public Administration, Faculty of Management Science, Lagos State \\ University, Ojo Campus, Lagos, Nigeria. \\ ${ }^{2}$ Department of Economics, Faculty of Social Sciences, Lagos State University, Ojo Campus, \\ Lagos, Nigeria. \\ ${ }^{3}$ Department of Economics, Faculty of Social Sciences, Lagos State University, Ojo Campus, Lagos, Nigeria.
}

\begin{abstract}
This paper examines the Nigerian experience of how the Human Resource (HR) experts contribute to corporate governance in the banking sector. Human resource experts have a key role to play in driving banks to achieve corporate governance objectives. The paper posits that HR involvement is a critical success factor for corporate governance and banks' performance. Human resource experts have the tools and the opportunity to leverage employee and other stakeholder's commitment to, and engagement in, the banks' corporate governance strategy. The ground for qualitative research in this paper is premised on the need to provide critical analysis between the corporate governance and HR within the context of the development of the Nigerian Banking services sector. Exploring qualitative research methodology provides lucid analysis of diverse thoughts which shape corporate governance-HR nexus as against quantitative research methodology where high level quantification would have been explored. The paper discovers that HR experts' roles in corporate governance have not been taken seriously by financial corporate organisations in general and banks particularly. The paper advocates that HR should add value to the firm by putting in place appropriate systems and mechanisms to ensure best practices in corporate governance are strictly adhered to. The contribution of this paper to knowledge lies in the fact that it augments the literature on the relationship between HR practices and corporate governance as it varies across national productive systems. This contribution enhances our knowledge about different strategies HR experts explore in managing corporate behaviour within the Nigerian banking sector for sustainable economic growth in Nigeria.
\end{abstract}

Keywords: Banking, Corporate Governance, Development, Economic growth, HRM/HRE,

\section{Introduction}

The issues of corporate governance keep on attracting considerable national and international attention. It is particularly of pertinence in the Nigerian banking industry where numerous financial failures, frauds and questionable business practices had adversely impacted on shareholders' confidence. The financial practices and performance of banks are important for the acceleration of economic growth and development of Nigeria and hence, the ongoing reforms in the banking industry by the CBN to enhance its global competitiveness. Banks being the engine room for economic growth in the developing economy (Sking and Levine, 1993); most important source of finance for business organisations and the main depository for the economy's savings presuppose that its corporate governance vis-a-vis HRM assumes a central role in the economic activities of nations. This is based on the fact that the Nigerian banking industry has significant role to play in the development of the country's economy. Thus, governance of financial institutions should aim at protecting the interests of all stakeholders, which include shareholders, depositors, creditors, regulators and the public (Ogbechie, 2011).

Corporate governance "deals with laws, procedures, practices and implicit rules that determine a company's ability to take managerial decisions vis-a-vis its claimants- in particular, its shareholders, creditors, the state and employees" (Mouli and Veena, 2012). Its objectives are to achieve a responsible, value-oriented management and control of companies. More concretely, it can be described as the processes and structures by which business and affairs of an institution are directed and managed in order to improve long-term shareholders values and respect of the legal rights of all shareholders in the context of its corporate mission (Alo, 2001). Sulaiman (2003) describes corporate governance as involving the balance of power with which organisation is directed, managed, supervised and held accountable. However, what constitute good corporate practices vary from one country, sector and organisations to the other and these variations are determined by different national legal codes, and sectoral and corporate cultures. Strongly connected with the process of corporate failure, is the process of corporate governance (CG). Thus, CG is basically concerned with doing the right things, and doing them right in an organisation through willing and able personnel to drive the organisation to success from time to time (ibid). 
Over the years, HR experts ${ }^{1}$ have not been challenged to think formally about functional governance issues- an approach to governance that focuses on performance (results) as well as conformance (compliance) to key support functions, especially HR. However, the recent corporate scandals in the banking sector have made all corporate and functional executives much more aware of their personal and legal accountabilities. In few cases where HR professionals have made explicit contributions, has been in the area of compliance while neglecting central issues as improving leadership and management, retirement, training and other human capital programmes (Beatty et al., 2003).

Human resource policies such as establishing acceptable behavioral standards, developing a code of ethics, using performance review process and rewarding employees for reducing waste or inefficiencies can help companies limit or prohibit negative employee situations. This can also improve overall employee expectations by putting these policies into the organization's corporate governance (ibid).

This paper becomes critical in the light of the challenges the Nigerian banking sector services has encountered in its governance in the last 100 years (1914-2014) of amalgamation and the role that HR experts are expected to play in repositioning the Nigeria's banking sector services for sustainable economic development. The interest in this direction is a timely signal to what could have ended up as a national problem, if the corporate governance in the banking sector services is not revamped to shoulder increasing responsibility for compliance with best practices and ultimately geared toward the promotion of economic growth and development.

Apart from the general introduction, this paper is divided into the following sections: section 2 dwells on problem analysis; section 3 sheds light on the literature review while section 4 discusses the research methodology. Section 5 critically discusses the challenges of corporate governance in Nigeria within the context of the role of financial regulatory agencies while section 6 treats corporate governance and banks' performance. The overview of corporate governance guidelines and codes of best practice in the Nigerian banks is captured in section 7 while section 8 considers Corporate Governance in Post-merger Integration Processes in Nigeria. Section 8 and section 9 discussed HRM and corporate governance and concluding remarks respectively.

\section{Problem Analysis}

Corporate wrongdoing is damaging investor's confidence and tarnishing the credibility of the Nigerian banking industry, guilty and innocent alike. The developing countries of Sub-Saharan Africa have also received limited attention because literature on corporate governance in SSA (and Nigeria in particular) has been largely descriptive with regards to the state of the subject in the third world (Bolodeokun, 2008; Okike, 2007). In this regard, Nigeria, Africa's largest market for goods and services and banking industry presents a good case where the subject matter has been attracting increasing local and notable international interests given the significant participation of foreign owned investments in the country's business sector. Corporate governance conduct in Nigeria has been conventionally characterised by endemic corruption (Ajogwu, 2007; Adegbite et al., 2010). Recent and ongoing development in Nigeria has increased concern for CG and accountability debate such as 2003 Code of CG in Nigeria; the 2006 mandatory code of corporate governance for Nigerian Banks Post consolidation; and 2007 Code of Conduct of Shareholders Associations in Nigeria; and notable/high profile corporate governance scandals in the banking industry as evident by widespread corrupt behaviour in the country's financial sector.

Therefore, the recent corporate scandals have shed increasing light on the inability of current systems as guided by $\mathrm{CBN}$ guidelines to effectively monitor and control top executive behaviour, who seemingly engaged in unethical and even illegal decision making that lined their own pockets while leaving the investors to pick up the bills (Wright, 2003). The banking industry stock market, which relies on trust in order to work efficiently, has floundered for over a year, in spite of recorded economic growth. Today, as a result of the recent turmoil and crises in the banking sector, corporate executives in the industry are believed to be less honest and trustworthy and larger percentage of the public have lost confidence in these banks. Strictly speaking, these incessant scandals have resulted in a crisis of trust. In view of all these failures and unethical behaviour, what is the role or connection of the HR expert? Responding to this question, it has been argued in certain academic quarters that some of the scandals are attributable to failure of senior members of the HR who have failed in their functions to play a leadership role in governance. This may largely be due to HR professional not being an integral enough a part of the senior management to be aware that such illegal or unethical decisions and behaviour were taking place. They may not be well placed in creating systems and controls to discourage such actions and in fact, may not act in the event of such behaviour. Still, senior HR professionals and leaders possess a fiduciary responsibility to shareholders and moral responsibility to employees in this respect.

\footnotetext{
${ }^{1}$ By HR experts, we mean human resource managers, human resource economist, human resource specialists and human resource professionals
} 
The discourse of the subject matter in the developed economies has been raised in the literature over a decade ago (Macay and O' Hara, 2001) while the corporate governance of banks in the developing economies (especially with particular reference to Nigeria) has been almost ignored by researchers and scholars alike (Caprio and Levine, 2002). On the one hand, there has been no study in the sector aimed at establishing relationships or involvement of HR professionals in corporate governance in the banking sector. While several studies on corporate governance and organisational performance (Mohammed, 2011; Olagunju and Oluwa, 2012) have been done, there is a dearth of empirical studies on the relationship between HR practices and corporate governance. The involvement of HR in corporate governance is a neglected area of research, most especially in the Nigeria banking sector. However, the country cannot afford to have ineffective and underperforming banking industry, which is seen as the engine room of the Nigerian economy. With the spate of reforms in the industry, understanding the governance of Nigerian banks and the attendant relationships that HR practices played in this respect is arguably more pertinent than ever before, following the attendant consequences of global financial meltdown. Importantly, the consistent bank failures and financial crisis during the last two decades has raised questions on the consistency and the workability of the corporate governance practices in the banking system (ibid)

This paper examines the Nigerian banking sector's experience on how the HR contributes to corporate governance. While several studies on the relationship between HR practices and organisational performance have been done outside the shore of Nigeria (Arthur, 1994; Huselid, 1995; Martell and Carroll, 1995; Delaney and Huselid, 1996; Youndt, Snell, Dean, and Lepak, 1996; Supangco, 2003, 2001a), there is a dearth of empirical studies on the relationship between HR practices and corporate governance in Nigeria or outside (Africa). Moreover, several studies on the involvement of the HR function in corporate strategy formulation have been done (Martell and Carroll, 1995; Buyens and De Vos, 2001; Supangco, 2001b) but involvement of HR in corporate governance in the banking sector is a neglected area of research. This study fills this gap by looking at specific HR roles and practices that are meant to support corporate governance.

\section{Literature Review}

In recent years, with growing interest in the relationship between corporate governance and HRM, a body of literature has emerged that finds patterns of relationship that vary across national productive systems (Gospel and Pendleton, 2005; Jacoby, 2005). For example, the market-oriented Anglo-American system is one in which the governance of public companies is directed towards dispersed-shareholder ownership and outsider control. In this context, the HRM function has traditionally been exposed to market pressures and has needed to react to stock market requirements; and this has been reflected in relationships between managers and employees. By contrast, the governance of continental European and Japanese corporations is characterized by dominant block-holder share ownership and insider control, which provides greater security for internal stakeholders (managers and employees) and a closer identification with the organization and its objectives. In this context, HRM plays a more pro-active role. Nevertheless, despite common features, there is also evidence of diversity across organizations within national systems (Gospel and Pendleton, 2005).

Corporate Governance in the banking system has assumed heightened importance and has become an issue of global concern because it is required to lead to enhanced services and deepening of financial intermediation on the part of the banks and enables proper management of the operations of banks. To ensure this, both the board and management have key roles to play to ensure the institution of corporate governance. Governance and performance should be mutually reinforcing in bringing about the best corporate governance. Transparency and disclosure of information are key attributes of good corporate governance which banks must cultivate with new zeal so as to provide stakeholders with the necessary information to judge whether interest are being taken care of (Ifeanyi et al., 2011). There is a consensus, however that the broader view of corporate governance should be adopted in the case of banking institutions because of the peculiar contractual form of banking which demands that corporate governance mechanisms for banks should encapsulate depositors as well as shareholders (Macey and O'Hara, 2001). Olugbemi (2002) joined the consensus by arguing that the special nature of banking requires not only a broader view of corporate governance, but also government intervention in order to restrain the behaviour of bank management. He further argued that, the unique nature of the banking firm, whether in the developed or developing world, requires that a broad view of corporate governance, which encapsulates both shareholders and depositors, be adopted for banks. They posit that, the nature of the banking firm is such that regulation is necessary to protect depositors as well as the overall financial system. The adoption of various economic reform programmes in Africa in the 1980's in which privatization of governmentowned enterprise forms a major plank, has heightened the corporate governance debate in the continent. The bitter experience of Asian financial crisis of the 1990's underscores the importance of effective corporate governance procedures to the survival of the macro-economy. This crisis demonstrates in no unmistakable terms that "even strong economies, lacking transparent control, responsible corporate boards, and shareholder rights can collapse quite quickly as investor's confidence collapse" and emphasizes the need to ensure effective corporate governance with a view to ensuring the development of market-based economies and democratic 
$H r$ - Corporate Governance Nexus: Implications For The Development Of Nigeria's Banking...

societies based on the rule of law (Amaeshi et al., 2006). For the banking sector, the retention of public confidence through the enthronement of good corporate governance remains of utmost importance given the role of the sector in the mobilization of funds, the allocation of credit to the needy sectors of the economy, the payment and settlement system and the implementation of monetary policy.

The financial sector with special reference to banking has come under the searchlight in recent years not only because of its strategic role as mediator of funds between the surplus and the deficit units but also as a result of the problem rocking the industry in terms of failure and eventual bankruptcy. Although, the banking sector serves as the nerve centre of any modern economy, being the repository of people's wealth and supplier of credits which lubricates the engine of growth of the entire economic system. The failure experienced in the sector over the years can be captured by the number of failed banks, the debt and extent of required capitalization, the proportion of non-performing credits, loss of depositor's funds and the general impact on the economy all of which underscores the importance of the sector.

Table 1: Records of Liquidated Banks in Nigeria

\begin{tabular}{|l|l|c|}
\hline S/N & \multicolumn{1}{|c|}{ PERIOD } & NO. LIQUIDATED \\
\hline 1. & Pre-independence & 22 banks \\
\hline 2. & 1992 & 3 banks \\
\hline 3. & 1994 & 4 banks \\
\hline 4. & 1998 & 26 banks(Recapitalisation era) \\
\hline 5. & 2005 & 14 banks \\
\hline 6. & 2009 & 5 banks (8 found weak out of 24) \\
\hline 7. & 2011 & $\begin{array}{l}\text { 3 banks (AMCON-Bridge } \\
\text { Banks/10 CEOs sacked by CBN) }\end{array}$ \\
\hline
\end{tabular}

Source: Authors compilation from CBN and NDIC in 2006, 2012.

The statistics above showed the total number of liquidated distressed merchant, commercial and universal banks in the sector from the pre-independence era to date. In 2011 as indicated in the table, three ailing banks were bailed out by AMCON and their names changed (Bridge banks) to avoid withdrawal of their licences and attendant consequences of such on stakeholders. In the same year, 10 CEOs of banks were sacked by the CBN on alleged of insider's abuses and other sharp practices.

\section{Methodology}

The methodological framework which governs this paper is qualitative. The ground for qualitative research for this kind of research is premised on the need to provide comprehensive analysis on the nexus between the corporate governance and HR within the context of the Nigerian Banking sector. Exploring qualitative research methodology will provides simple and critical analysis of diverse thoughts which shape corporate governance-HR nexus as against quantitative research methodology where high level quantification would have been explored. The use of qualitative research methodology also eliminates the use of some basic assumptions (ceterisparibus) ${ }^{2}$, even where such assumptions are inadequate for capturing the fundamental issues that will critically explain the corporate governance-HR relationship within the Nigerian Banking sector. However, this research is not meant to downplay the adoption of quantification in the study of corporate governance-HR as it relates to the Nigerian banking sector. Rather, it provides justifications for the adoption of qualitative research.

The paper draws on content analysis ${ }^{3}$. Content analysis encourages triangulation to bridge micromacro dichotomy in data collection methods. To this end, the paper draws on multiple methods of data collection including: secondary review of existing literature in corporate, HR and banking; statistical information from the publications of Bureau of Statistics, CBN, NDIC and Bankers Committee.

\section{Challenges of Corporate Governance in Nigeria: The Role of Financial Regulatory} Agencies

The budding literature on corporate governance in sub-Saharan Africa (and Nigeria in particular), has been largely descriptive with regards to the state of the subject in the third world (for example see: Ahunwan 2002; Bolodeoku 2006, 2008; Ajogwu 2007; Okike 2007). Most notably, these descriptions have taken a dominant internal focus, and limited attention has been paid to the external influences on the evolving landscape of corporate governance and accountability in the region. Thus, Nigeria presents an evolving corporate

\footnotetext{
${ }^{2}$ It is a Latin phrase which means all things being equal.

${ }^{3}$ In this research, content analysis is seen as 'a research technique for the objectives, systematic and qualitative description of the manifest content of communication' (Selltize, 1977).
} 
governance system, significantly influenced by notable agents of convergence, and therefore provides a rich platform from which to examine the influences shaping the evolution, construction, expectation and expression of corporate governance in developing countries.

Recently in Nigeria there has been a series of legislative, economic and financial reforms that intended to promote transparency, accountability and the rule of law in the economic life of the country. All these are intended to consolidate the foundation and principles of corporate governance in the Nigerian economy. For an emerging economy such as Nigeria CG is of vital importance. In recent times, the inadequacy or total lack of CG has led to economic upheavals. For example, in the late 1980 and early 1990s the country witnessed a near collapse of the financial sector through the phenomenon of failed banks and other financial institutions. In consequence, the Failed Banks (Recovery of Debt) and Financial Malpractice in Banks Act was promulgated to facilitate the prosecution of those who contributed to the failure of banks and to recover the debt owed to the failed banks (see Sanusi, 2010, 2011a and 2011b; Ifeanyi et al., 2011). Secondly, the privatization and commercialization programme of the Nigerian Government was a reaction to the failure of corporate governance in state owned enterprises (SOE). Experience in the country has however shown clearly the poor levels of corporate governance in both public and enterprises, including the banking industry. The first example is Savannah Bank. The Central Bank of Nigeria withdrew the banking license of Savannah Bank on Feb 15, 2002 because of a number of reasons. In a press release dated 18th February 2002, The CBN listed the reasons as the ineffectiveness of the board as well as the ineptitude and instability of the management; the false and unreliable returns to the regulatory authorities; the insolvent and deteriorating financial position of the bank; and the urgent need to protect the interest of depositors, both existing and prospective and the banking system and the inability of the bank to respond to various regulatory initiatives (See Ifeanyi et al., 2011).

The second example of the failure of corporate governance in privately owned companies is the revocation of the banking license of Peak Merchant Bank by the Central Bank of Nigeria. In a press release dated 28th February 2003, the apex bank noted that the bank had been licensed on 15th February 1991 and that it was revoking its license because of weak and incompetent management; insolvency; the over bearing influence of the Chairman who was also the majority shareholder of the bank; persistent liquidity problem; poor asset quality; significant insider abuses; poor track of profitability; un-seriousness, inability and unwillingness of shareholders to recapitalise; reckless granting of credits; complete absence of focus and lack of corporate governance (NDIC, 2005).

Given that corporate conduct in Nigeria has been conventionally characterised by endemic corruption, recent and ongoing developments in the country have added an energetic momentum to the budding corporate governance and accountability debate (Yahaya, 1998; Okike, 2004, 2007; Yakasai, 2001; Ahunwan, 2002; Bolodeoku, 2006, 2008; Ajogwu, 2007; Adegbite and Nakajima 2010; Adegbite, Amaeshi and Amao, 2010). These include the 2003 Code of Corporate Governance in Nigeria; the 2006 mandatory Code of Corporate Governance for Nigerian Banks post consolidation; and the 2007 Code of Conduct for Shareholder Associations in Nigeria; and notable/high profile corporate governance scandals. Indeed, widespread corrupt corporate behaviour as exemplified by ongoing corporate disasters as well as near-disasters particularly in the country's financial sector, has brought to the fore the imperativeness of effective governance and accountability in modern day Nigerian corporations. Notably these have brought corporate governance discussions to the pinnacle of academic, practice and policy debates in Nigeria. As a result, while South Africa may be the leading contributor, (Vaughn and Ryan, 2006) corporate governance developments in Nigeria are becoming increasingly notable in the African corporate governance literature.

The Central Bank of Nigeria in its continuing efforts to enhance corporate governance in the Nigerian banking system has come up with the Corporate Governance Code which is intended to promote international best practice in the corporate governance of Nigerian banks. The Code draws upon international best practice, in particular the Organisation of Economic Corporation and Development (OECD) principles of Corporate Governance and the guidance issued by the Basel Committee on Banking Supervision in their publication: Enhancing Corporate Governance for Banking Organizations. However, it is worthy to note that the interest in corporate governance is not limited to governmental or banking institutions, some private forums and associations have also been established to enhance the adoption of the concept of corporate governance. The major elements of corporate governance are good board practices, control environment, transparent disclosure, well defined shareholder rights and board commitment. The four pillars of corporate governance are accountability, fairness, transparency and independency (Amaeshi et al., 2006). It can be concluded that although, corporate governance can be defined in a variety of ways, generally, it involves the mechanisms by which a business enterprise organized in a limited corporate form is directed and controlled. It usually concerns mechanism by which corporate managers are held accountable for corporate conduct and performance.

Corporate Governance is mainly to ensure a strong and reliable banking industry where there is safety of depositors' money and also to develop the required flexibility to support the economic development of the 
Hr - Corporate Governance Nexus: Implications For The Development Of Nigeria's Banking...

nation by effectively performing its functions. Corporate governance aims to create an atmosphere whereby Nigerian banks will comply with the laid down rules and regulations without compromise. This will in the end lead to transparency in the banking institutions, proper risk management, adoption of best practices in carrying out duties, strong internal control system, restoration of public confidence, rapid economic growth and in all prevent bank distress which might eventually lead to bank failure (Ifeanyi, et al.,2011).

\section{Corporate Governance and Banks Performance}

It has been argued that the governance structure of banks has little or no relationship to their financial performance due to the presence of external regulators at both the state and federal level. Consistent with this statement, Simpson and Gleason (1999) found that there was no relationship between the structure of banks' board of directors and subsequent failure. Further, Chukwudire (2004) argues that the change in corporate control in commercial bank is the result of regulatory intervention. As evidence by the recent crisis, it is apparent that regulatory forces were not effective in promoting a safe and fair allocation of bank resources. It is important to demonstrate that even in the presence of regulation, weak corporate governance was a contributing factor to the poor performance underlying the subprime crisis and to poor loan quality. Prior research suggests that banks strongly influence economic development and the efficient allocation if funds resulting in a lower cost of capital to firms, a boost in capital formations, and an increase in productivity (Ogbechie, 2011). The passing of various Acts which deregulated the banking industry heightened the importance of internal regulatory mechanisms of banks such as corporate governance. In particular, corporate governance is expected to affect bank's valuation, cost of capital, performance and risk taking behaviour (Olugbemi, 2011).

Banking supervision cannot function well if sound corporate governance is not in place, and consequently, banking supervisors have strong interest in ensuring that there is effective corporate governance at every banking organisation. Changes in bank ownership during the 1990s and early 2000s substantially altered governance of the world's banking organizations. In the banking industry, well-functioning banks promote economic growth. When banks efficiently mobilize and allocate funds, this lowers the cost of capital to firms and accelerates capital accumulation and productivity growth. In addition, banks play important roles in governing firm to which they are major creditors and in which they are major equity holders (Caprio, Leaven and Levine, 2004). Thus, if bank managers face sound governance mechanisms, this enhances the likelihood that banks will raise capital inexpensively, allocate society's savings efficiently, and exert sound governance over the firm they fund. Generally, banks occupy a delicate position in the economic equation of any country such that its performance invariably affects the macro economy of the nation. Poor corporate governance may contribute to bank failures, which can pose significant public costs and consequences due to their potential impact on any applicable deposit insurance systems and the possibility to broader macroeconomic implications, such as contagion risk and the impact on payments system. In addition, poor corporate governance can lead markets to lose confidence in the ability of a bank to properly manage its assets and liabilities including deposits, which could in turn trigger a bank run or liquidity crisis (Olagunju and Oluwa, 2012). The economics and functions of banks differ from those of industrial firms. Because of these differences, banks are subject to stringent prudential regulation of their capital and risk. Moreover, these differences are reflected in corporate governance practices observed in the banking sector and in theoretical works on the "good corporate governance of banks". With respect to corporate governance practices, a particularly striking and almost unique feature of banks has been the prevalence of remuneration schemes that provide high-powered incentives, not only for executive directors (officers), i.e., members of the management board in a two-tier system, but also for senior managers at lower levels, and even for more junior employees in some functions, in particular the trading and sales function. The performance of the individual banks which makes up the banking sector is a function of the decisions of the management governing these banks. In other words, corporate governance has a major role to play in the development of the banking sector. This is in line with the argument of Mohammed (2011) that the concern over corporate governance stems from the fact that sound governance practices by organisations, banks inclusive results in higher firm's market value, lower cost of funds and higher profitability.

\section{Overview of Corporate Governance Guidelines and Codes of Best Practice in the Nigerian Banks}

The fundamental concern of corporate governance is to ensure the means by which a firm's managers are held accountable to capital providers for the use of assets. The responsibilities and functions of the corporate board in both developed and developing nations are receiving greater attention as a result of the increasing recognition that a firm's corporate governance affects both its economic performance and its ability to access low-cost capital. After all, the board of directors - or, in two-tier systems, the supervisory board - is the corporate organ designed to hold managers accountable to capital providers for the use of firm assets. The past five years have witnessed a proliferation of corporate governance guidelines and codes of "best practice" designed to improve the ability of corporate directors to hold managements accountable. This global movement 
$H r$ - Corporate Governance Nexus: Implications For The Development Of Nigeria's Banking...

to emphasize that boards have responsibilities separate and apart from management, and to describe the practices that best enable directors to carry out these responsibilities, is a manifestation of the importance now attributed to corporate governance generally and, more particularly, to the role of the board.

Corporate governance guidelines and codes of best practice arise in the context of, and are affected by, differing national frameworks of law, regulation and stock exchange listing rules, and differing societal values. Although, boards of directors provide an important internal mechanism for holding management accountable, effective corporate governance is supported by and dependent on the market for corporate control, securities regulation, company law, accounting and auditing standards, bankruptcy laws, and judicial enforcement. Therefore, to understand one nation's corporate governance practices in relation to another's, one must understand not only the "best practice" documents but also the underlying legal and enforcement framework.

In the developing nations, governance codes are more likely to address basic principles of corporate governance that tend to be more established in developed countries through company law and securities regulation, such as the equitable treatment of shareholders, the need for reliable and timely disclosure of information concerning corporate performance and ownership, and the holding of annual general meetings of shareholders. However, in both developed and developing nations, codes focus on boards of directors and attempt to describe ways in which boards can be positioned to provide some form of guidance and oversight to management, and accountability to shareholders and society at large.

According to Adegbite and Amaeshi (2010) a deeper investigation into the governance practices of today's Nigerian corporations suggests that the influential Anglo-Saxon precedence remain vibrant. For example, the principles, upon which regulatory initiatives and policy formulations in the area of corporate governance in Nigeria are based, are British in origin and still resemble that of the UK. Furthermore, whilst Nigeria's attainment of independence led to the replacement of the Companies Ordinance of 1922 by the 1968 Companies Act, the UK corporate law remained a huge influence; for example, the 1968 Companies Act extensively mirrored the UK Companies Act of 1948 (Okike, 2007). Although there have been company law reforms in both countries over the years, the legal system of corporate governance in Nigeria has remained fashioned along the Anglo-British model. As a result, shareholders have, albeit in principle, enjoyed many of the same legal rights as shareholders in the dominant Anglo-Saxon economies (Ahunwan, 2002). However, given the socio-economic and political misfit of this Anglo-Saxon peculiar corporate governance regime, the corporate governance system in Nigeria has historically been incapacitated to tackle local challenges. Indeed, Nigeria lacks an effective judicial system to enforce these Anglo-Saxon defined rights, which has traditionally increased the costs of contracting as well as making business activities much more risky ventures (Ahunwan, 2002). As a result, while the legal underpinnings are a reflection of the UK framework, it would be unwise to assume that Nigeria mirrors the UK in terms of application (Okike, 2007). These "application and enforcement problems" have been worsened by widespread corruption, an endemic problem which has penetrated all areas of the country's economy. Indeed the problems of corporate governance in Nigeria are part of a larger problem of the Nigerian society which is characterised by political instability, bad leadership, ethnic rivalry and religious tensions.

\section{Corporate Governance in Post-merger Integration Processes in Nigeria}

In the CBN Code of Corporate Governance for Banks in Nigeria Post-Consolidation, the apex banking regulator stipulates as follows:

i. Government equity holding in any bank shall be limited to $10 \%$ by the end of 2007 , as government is enabling a private sector-led economy.

ii. Equity holding of over $10 \%$ by any single investor shall require CBN approval.

iii. No individual will combine the positions of Chairman and CEO, and, in the new era, such title as Executive Vice Chairman is not recognised.

iv. No two extended family members can hold simultaneously the positions of Chairman and Chief Executive Officer.

The code now discourages sit-tight board predilection as fresh ideas are constantly required in steering the banks. Banks that makes a false rendition of its reports to the CBN could have its CEO dismissed and blacklisted as a non-first-time offender. It is observed that most of the threats to corporate survival of banks hover around accountability and transparency. According to Sanusi (2011), the post-consolidation era gave impetus to rapid growth in the money and capital markets due to increase in liquidity in the banking industry. The banking sector, however, witnessed the dearth of risk management skills and sound corporate governance. The crash of the stock market due to overrated value of banks' shares in the capital market also took a huge toll on the banking industry. Undoubtedly, the crisis gave the regulatory and supervisory authorities sleepless nights. In 2009, the CBN and NDIC embarked on special joint examination of the 24 banks to determine their financial conditions. The report showed that weak corporate governance, operational indiscipline, illiquidity, insider 
Hr - Corporate Governance Nexus: Implications For The Development Of Nigeria's Banking...

abuses and other sharp practices were prevalent in the banking industry. It was also revealed that eight out of the 24 banks were in grave financial difficulties to honour their maturing obligations to depositors. Consequently, the CBN injected N620 billion into the eight ailing banks. The apex bank, in collaboration with the NDIC, also appointed interim management boards to take control and management of the intervened banks. The reversal from the universal banking practice to the specialised banking model was equally a move to enhance the quality of the banks and their contributions to the real sector of the economy.

In 2010, the Asset Management Corporation of Nigeria (AMCON) was established following the promulgation of its enabling Act by the National Assembly. The Corporation is a special purpose vehicle aimed at addressing the problem of non-performing loans in the Nigerian banking industry, among others. In line with its mandate, AMCON recently acquired the non-performing assets of some banks, worth over N1.7 trillion, which is expected to boost their liquidity as well as enhance their safety and soundness. With the intervention of AMCON, the banking industry ratio of non-performing loans to total credit has significantly reduced from 34.4 per cent in November 2010 to less than 5.0 per cent as at December 2012. Sanusi (2011) noted that in order to ensure that AMCON achieves its mandate, the CBN and all the deposit money banks have signed a MoU on the financing of AMCON. The CBN shall contribute N50 billion annually to AMCON, while each of the participating banks shall contribute an amount equivalent to 0.3 per cent of its total assets annually into a sinking fund as at the date of their audited financial statement for the immediate preceding financial year. Therefore, the cost of resolution to the Nigerian taxpayer is significantly minimized. Mainstreet Bank Limited, Enterprise Bank Limited and Keystone Bank Limited, were establishment as bridge banks by the NDIC as resolution option for three ailing banks, namely, Afribank Plc, Spring Bank Plc and BankPHB Plc, respectively. The assets and liabilities of the ailing banks were transferred through AMCON to the respective bridge banks. Statistics showed that this singular option safeguarded N809 billion total deposit liabilities as at August 2011. Since the establishment of the bridge banks in 2011, five other intervened banks had concluded their Transaction Implementation Agreements. The shareholders of Intercontinental Bank Plc, Oceanic Bank Plc, Finbank Plc and Equitorial Trust Bank Plc had endorsed their mergers with Access Bank Plc, Ecobank Plc, First shareholders and African Alliance group.

Table 2: Significance of different factors in the failure of some banking organisations in Nigeria

\begin{tabular}{|c|c|c|c|c|c|c|c|c|}
\hline Banks & $\begin{array}{l}\text { Ethics /Culture } \\
\text { at the top } \\
\text { /Disclosure and } \\
\text { transparency }\end{array}$ & CEO's & $\begin{array}{l}\text { Board of } \\
\text { Directors }\end{array}$ & $\begin{array}{l}\text { Internal } \\
\text { Controls }\end{array}$ & $\begin{array}{l}\text { Aggressive } \\
\text { Earnings } \\
\text { Mgt. }\end{array}$ & Political & $\begin{array}{l}\text { Stakehold } \\
\text { ers roles }\end{array}$ & $\begin{array}{l}\text { High level } \\
\text { of } \\
\text { nonperformi } \\
\text { ng loans }\end{array}$ \\
\hline Oceanic & *** & *** & $* *$ & $* *$ & * & - & - & - \\
\hline Intercontinental & $* *$ & $* * *$ & $* *$ & $* *$ & $*$ & - & - & - \\
\hline Bank PHB & $* *$ & $* * *$ & $* *$ & $*$ & $*$ & - & - & - \\
\hline Afribank & $* *$ & $* * *$ & $* *$ & $*$ & $*$ & - & - & - \\
\hline Savannah & $* *$ & $* * *$ & $* *$ & $*$ & - & $* *$ & $*$ & - \\
\hline Spring & $* *$ & $* * *$ & $* *$ & $*$ & - & - & - & - \\
\hline
\end{tabular}

Source: CBN 2006 and Authors' compilations

Keys: *= Issue has relatively minor significance; $* *=$ Issue has moderate significance;

$* * *=$ Issue has major significance

The above are factors about governance that can lead to the demise or fall of a bank as observed in the study. First and foremost is the aspect of disclosure; that is, corporate information disclosure. The experiences of most of the banks and auditors that look the other way have left the need for a lot to be done and questioned in bank organizations, when it comes to disclosure and transparency. What is that information that an organisation in the sector provides for and what is it that it needs to do in order that this information is properly disseminated among its shareholders in particular and public in general? Does publishing a good annual report tantamount to and encompass all issues pertaining to what is known as Fair Disclosure? And how is information in the annual report stated? Is it lucid and understandable to the ordinary investor? For instance, most of the bank's Annual reports are often not very clear because they are distorted, doctored and misleading. This position has been vividly captured in the literature that:

...some companies use creative accounting techniques to disguise damaging information, to provide a distorted picture of the financial health of the business, to smoothen erratic earnings, and to boost anaemic and fluctuating financial reports. Business are often clever in hiding these accounting tricks and gimmicks; so, analysis and interpretation must take cognisance of the signs of outright financial manipulation or outright good fortune and potential of the business... (Adegbite, 2010, pg. 8-9).

The second aspect pertains to leadership. Most bank organisations which have faced a demise have had at their centre a high profile CEO/MD, (see Oceanic, Intercontinental, Bank PHB, Afribank etc.) a person who more likely than not, thought about the bank as his/her own fiefdom which could be run according to his/her 
rules. In this study, we observed that in most cases, the CEO played a greater role in the Nigerian banking business failure, than any other factor. A third aspect pertains to ethics and moral conduct (morality as related to/or pertaining to business issues/matters), generally prevalent in the organisation, i.e how the organisation views, and acts on matters pertaining to these issues. Very few bank organisations immediately come to our mind as organisations which conduct business ethically. The question therefore is can HR play a role in all of this?

\section{HRM and Corporate Governance}

At this point, it is interesting to determine the role of HR involvement in the formulation of policies and practices in support of governance. The recent emphasises among practitioners and academics on "people" (and people management systems) as a source of competitive advantage has focused increasing interest on the science and practice of HRM/HRE ${ }^{4}$. Indeed, it would appear that the field of HRM/HRE is "coming of age" due to its strategic approaches to business success. While academic research has made a number of significant contributions to these developments, very few studies has addressed the subject matter as it relates to CG in banks. Using the resource-based perspective, Lado and Wilson (1994) argued that HR practices may be a source of competitive advantage. When such practices are aligned with strategies, they become idiosyncratic to the organisation (Becker and Gerhart, 1996). The idea may be applied to practices supporting corporate governance. The resource-based view is consistent with contingency theory implying that strategies are not universal; rather, they are contingent on the organization's employees who implement them (Wright, 2003). HR's involvement in strategy formulation enhances the alignment of HR practices with the organization's strategy; this argument may be extended to the organization's corporate governance objectives (Buyens and Devos, 2001). In providing the environment within which the implementation of HR strategies becomes effective, Lengnick-Hall (1988) explained that the integration of HR with strategic choices is important because when resources including HR are examined in goal setting and implementation, a broader range of solutions to complex problems becomes more likely.

By extension, when HR is involved in crafting policies and practices that enhance alignment of individual interests with corporate interests, implementation of such will also be enhanced to the extent that such concern provides the means where information necessary for execution are exchanged and utilized (Amit and Schoemaker, 1993). Participation of the HR function in strategy formulation and specifically in crafting strategies aimed at supporting corporate governance is an intricate process and becomes rooted in a firm's social structure. Such processes facilitate the development of strategies peculiar to the firm.

\section{Conclusions}

In this study, we have observed that the involvement of HR experts in the institutionalization of corporate governance in Nigeria is beneficial to the banks and other financial institutions, the various stakeholders and the economy at large. Adherence to corporate governance ethics drives corporate survival, performance and excellence. Following the issue of corporate survival and growth is the benefit of increased employment. Since firms (banks) which otherwise would have gone under survive, their employees remain. In addition, more persons are employed as the firms grow. The employees become more dedicated in an environment where their rights are assured and respected. These no doubt would ensure that public confidence (banks' most important asset) is maintained through appropriate disclosure and maintenance of high ethical standards and professionalism conduct in the banking sector.

HR experts are expected to play an active role in ensuring that they build an ethical banking organization that followed the code of corporate governance in the banking sector for the sustainability of economic growth in Nigeria. In the light of this, it is proposed that HR experts be elevated to a position of power and primacy in the banking sector, with the possession of special qualities to help managers build leaders and careers in the sector. Banks with high ethical standards are more likely to reach strategic goals, are viewed more positively by stakeholders, are better able to attract and retain human resources.

In sum, HR must devote considerably more wide-eyed effort and attention to assessing the honesty and integrity of organizational decision makers. In some cases, these assessments may lead to termination, or failure to promote. In other cases, they may lead to additional controls. However, assessments must be thorough, ongoing, and in all aspects of an individual's life. It is hard to believe that most of the top executives of banks in Nigeria who are now suspected, indicted, or convicted of illegal behaviour have been liars, cheats, and/or corporate thieves for their entire careers without no one (HR practitioners) noticing early enough in the organisations nor the financial regulators. By the constant fall of water drops a pitcher is filled; likewise, the unwise person, accumulating evil little by little, becomes full of evil. Similarly, fraudulent bank officials were probably not always bad. Rather, as they constantly brushed up against the legal and ethical boundaries, they

${ }^{4} \mathrm{HRM} / \mathrm{HRE}$ means human resource management and human resource economics. 
Hr - Corporate Governance Nexus: Implications For The Development Of Nigeria's Banking...

probably discovered they had crossed it without knowing, only to be alerted by CBN and other regulators. HR professionals need to keep these bank executives from getting close to the boundaries, and speak up as soon as they cross them in the interests of the shareholders and all other stakeholders as well as in line with the professional codes of conduct.

Understanding HR's role in executive compensation should be obvious. Competent HR professionals have the best knowledge of the impact of incentives, both functional and dysfunctional, relative to anyone else in the firm. Yet, given the prevalence of these scandals or even more recent negative press (e.g., Bank executives huge 'compensation' packages provided at the same time they were demanding unions to take significant wage cuts), one would think (or at least hope) that HR was nowhere to be found. For instance, we know that tying pay to any performance measure will have the potential for dysfunctional consequences, so why would stock based compensation be any different? Did the vast amounts of money made by executives ever appear on the radar screens of HR as something that may potentially distort decision making? The point is not that stock-based compensation should be eliminated, that executive pay is too high, or that CEO's should be precluded from earning any outside income. However, it appears that in most cases, these questions were never even asked. HR executives seemed either bought off (with huge pay packages of their own), implicitly threatened (with discharge for resisting these pay packages) or ignorant. None of these alternatives are particularly flattering. However, this highlights the importance of HR professionals who possess the competence to understand all the consequences of incentive systems, and the courage to speak up. As an expert in reward management, HR professionals have a critical role to play in reward risk management and governance, and must abandon the status quo where HR's role has often been seen as peripheral in corporate governance issues. To be able to make effective contribution here, HR professionals must work closely and gain credibility with other key stakeholders, particularly the board of directors and senior executives. Thus, HR must build a collaborative relationship with the board of directors, particularly the remuneration committees, ensuring in particular that there is in existence a formal and transparent procedure for developing policy on executive remuneration (see Adeleye, 2009; Ajogwu, 2009 and CIPD, 2009). It has been observed that:

...there are cases where the total remuneration package of directors and top management have no link with their abilities and performance...; the participation of shareholders in determining the remuneration of the board to formulate and disclose a remuneration of the board is encouraged in the new order which requires the board to formulate and disclose a remuneration policy highlighting the long run link between performance and remuneration...the corporate governance stance is that remuneration of executive and directors should be transparent, fair, and reasonable (Chukwudire, 2004, pg.16).

Obviously, the choice and management of auditors and tax consultants is not something that was ever an interest of top HR executives. In addition, some HR executives have little say over the choice of board members. However, most of these scandals in the banks should provide adequate incentives for HR to expand its view of where it should be involved. Who within the organization better understands incentives, and how such incentives can create conflicts? Just as they should have noted the internal conflicts between analysts and investment bankers within their firms, they should be best able to identify potential conflicting incentives within different units of the banks. In addition, HR certainly must become more involved in the selection of board members. Their focus for the future must be not just on the competence of the members, but those potential members' relational networks.

Moreso, HR can play a lead role in directing the processes for board functioning. Many firms have gone to evaluating boards and board members. Many have begun requiring or subsidizing board members to receive training. Many have moved to having chances for the boards to meet without managers present. Again, the competencies of top HR executives such as team building, group processes, selection, training, performance management, etc. are all critical to an effectively functioning board. In fact, it is an observable fact that nepotism in the appointment and promotion of management staff especially in the privately owned banks has contributed largely to the level of incompetence, inadequacy and sharp practices within the sector. Consequently, HR's role must expand to include these activities at the board, not just at the organization level. This is no doubt is in line with set of best practices that are critical which banks must deal with to strengthen their governance structure. Relate to this are optimum size of the board; the selection of directors; the mix of skills and experiences to be represented on the board. Little wonder Olugbemi noted that the board ... vis-a-vis HR professionals should fulfil key functions as: '... selecting, compensating, monitoring and when necessary, replacing key executives and overseeing succession planning’ (Olugbemi, 2011, pg.46).

Against this backdrop, effective corporate governance is all about the board's performance. The task of governing a corporate entity is the work of board of directors. If the company is to be governed effectively, the board needs to be made up of the right people, and each of these people must play their part in the corporation. For a board to function effectively, it should be composed of members who are independent, skilled, knowledgeable, experienced and of diverse perspectives. 
The HR traditional roles of strategic partner, employee advocate, administrative expert, and change agent have not disappeared, nor will they decrease in importance. However, these Bank scandals and failures undoubtedly added to these current responsibilities one of serving as an 'integrity officer' (Wright, 2003). Some firms have often used HR professional as their ethics or compliance officers, but this new role goes beyond a simple structural arrangement. Top HR executives must actively and constantly analyze the environment faced by top decision makers. They must accurately identify the pressures and incentives that could encourage these decision makers to put self interest above the organisation's interests. They must consistently assess the evolving character of decision makers, recognising that individuals who had high integrity, and may still aspire to high integrity, can slowly, and incrementally slide down a path of destruction. They must expand the focus of relevant organizational actors beyond internal executives to include auditors, consultants, investment bankers, and board members, and be on constant vigil to spot potential conflicts of interest. Most importantly, at the first hint of dishonest behaviour, HR executives must have the confidence and courage to explicitly and specifically put it on the table for top managers and/or the board to see. Interestingly, many executives refer to the HR function as serving a role as the "conscience" of the organization (Beatty et al., 2003). While a "conscience" should infiltrate all organizational members rather than be isolated in one function, certainly HR professionals must take this role seriously in our banks. Such a role creates a conflict that the field must recognize and to which it must respond.

Top HR executives are most often hired and fired by the CEOs. When HR executives serve at the pleasure of those they may be called upon to call out, they cannot be sufficiently independent to be expected to do so. Consequently, this may call for exploring changes in the employment relationship of top HR executives. Perhaps HR executives should have a direct reporting relationship to the board of directors. Or, maybe their employment contracts should include significant clauses of protection for top HR executives who may be fired for effectively playing this "conscience" role (ibid). The point here is not to suggest the perfect answer, but to recognize that all of the issues discussed above as potential causes of $\mathrm{CEO} /$ top management misbehaviour can similarly characterise the situations of HR executives. Consequently, as the field seeks to play a role in designing systems to encourage honest behaviour in CEO's, it must simultaneously examine its own situation to ensure that these systems cannot be circumvented (Buyens and De vos, 2001).

No one can blame the problems that have resulted in the current banking crisis of trust on HR professionals. Clearly, bad bank management and officials, with incentives to do bad things, functioning under inadequate controls and working within a flawed system resulted in the problems we see today. HR did not cause this problem. However, to say that HR did not cause the problem does not absolve HR from responsibility. Suffice to mention that if these steps are taken as suggested here, it would help to avert or reduce to the barest minimal another corporate scandal in the sector. Therefore, HR executives must be vigilant, diligent and proactive to stem the trend and nipped in the bud such sharp practices that are contrary to corporate governance best practices before another crisis and financial scandals in the sector breaks. As custodian of legal and moral obligations of organisations, HR professionals in the sector must be vast and versatile with the code of corporate governance in the sector and ensure each bank's strict adherence to the existing code of conducts by bank CEOs and top management at large.

\section{References}

[1]. Adegbite, F.F. (2010), 'Interpretation of Financial Statements and Lending to Corporate Clients in the Nigerian Banking Industry', in the Nigerian Banker, pp. 7-13.

[2]. Adegbite, E. and Nakajima, C. (2010), 'Institutional determinants of good corporate governance: The case of Nigeria', The Academy of International Business (UK + Ireland Chapter) 37th Annual Conference, April 8th -10th.

[3]. Adeleye, I. (2009), 'Risk Management and Reward Systems: Taking HR Governance Seriously', In HRM Journal of Chartered Institute of Personnel Management, Vol. 1, no: 2, pg.13-25.

[4]. Ahunwan, B. (2002) 'Corporate governance in Nigeria' Journal of Business Ethics, 37: 269-287

[5]. Ajogwu, F. (2007), Corporate Governance in Nigeria: Law \& Practice Centre for Commercial Law Development, Nigeria.

[6]. Alo, O.(2001), 'Ethical Values and Professionalism of Responsible Corporate Governance of Nigerian Banks', Paper presented at the first 2001 Quarterly Forum of the Bank Directors' Association of Nigeria.

[7]. Amaeshi, K.M., Adi, B.C., Ogbechie, C. and Amao, O.O. (2006), 'Corporate social responsibility (CSR) in Nigeria: Western mimicry or indigenous practices?', Research Paper Series: International Centre for Corporate Social Responsibility, University of Nottingham.

[8]. Amit, R. and Schoemaker, P.(1993), Strategic assets and organizational rent in Strategic Management Journal, 14, pp. 33-46.

[9]. Arthur, J. B. (1994). "Effects of human resource systems on manufacturing performance and turnover", in Academy of Management Journal, 31: 670-87.

[10]. Beatty, R.W., Ewing, J.R. and Tharp, C.G.(2003), HR's Role in Corporate Governance: Present and Prospective', in HRM, Wiley Periodicals, Inc., Vol. 42. No.3, pp. 257-269.

[11]. Becker, B. and Gerhart, B. (1996), The Impact of human resource management on organizational performance: progress and prospects. Academy of Management Journal, 39(4), pp. 779-801. 
[12]. Beer, M. and Spector, B.(1985),Corporate Transformation in Human Resource Management, in Wallon, R. and Lawrence, P. (eds.) HRM Trends and Challenges, Boston, MA Havard University Press

[13]. Bolodeoku, I. (2006) 'Corporate governance: The law's response to agency costs in Nigeria' Brook J. Int.l L 32(2) 467.

[14]. Bolodeoku, I. (2008) 'Filling the gaps in the legislative framework for audit committees of listed companies in Nigeria', Corporate Ownership and Control, 6 (2): 166.

[15]. Buyens, D. and De Vos, A. (2001), Perception of the value of the HR function. Human Resource Management Journal, 11(3), pp. 70-89.

[16]. Caprio, G. and Levine, R. (2002), “Corporate Governance of Banks: Concepts and International Observations”, paper presented at the Global Corporate Governance Forum Network Research Meeting

[17]. Chandra Mouli, V.V and Veena, V. (2012), 'HR and Governance' www.visisht.com, Accessed 29/02/2012

[18]. Chukwudire, C.(2004), 'Corporate Governance in the Nigerian Financial Service Industry', in the Nigerian BankerJournal of the Chartered Institute of Bankers of Nigeria, pp. 15-20.

[19]. CIPD (2009), 'Managing Reward Risks: A Integrated Approach', London: CIPD

[20]. Delaney, J. and Huselid, M.(1996), The impact of human resource management practices on perceptions of organizational performance. Academy of Management Journal, 39(4), pp. 949-969.

[21]. Gospel, H. and A. Pendleton (2005), Corporate Governance and Labour Management: An International Comparison. Oxford: Oxford University Press.

[22]. Holly J. G.(2012), 'Overview of Corporate Governance Guidelines and Codes of Best Practice in Developing and Emerging Markets' in Robert A.G. Monks Nell Minow, Corporate Governance ( $3^{\text {rd }}$ edition).

[23]. Huselid, M. (1995), "The impact of human resource management practices on turnover, productivity and corporate financial performance". Academy of Management Journal, 38: 635-70.

[24]. Jacoby, S. (2005), The Embedded Corporation: Corporate Governance and Employment Relations in Japan and the United States. Princeton: Princeton University Press

[25]. Lado, A. A. and Wilson, M. C. (1994), Human resource systems and sustained competitive advantage: A competency-based perspective. Academy of Management Review, 19(4), pp. 699-727.

[26]. Lengnick-Hall, C. and Lengnick-Hall, M. (1988), Strategic human resource management: A review of literature and proposed typology, in Academy of Management Review, 13(3), pp. 454-470.

[27]. Macay, J. and M. O"Hara, (2003), "The Corporate Governance of Banks", Federal Reserve Bank of New York Economic Policy Review, April 5, pp. 91 - 107.

[28]. Martell, K. and Carroll, S. J. (1995), Which human resource management practices for top management team are associated with higher firm performance? Human Resource Management, 34(4), pp. 497-512.

[29]. Mohammed, F. (2011), 'Impact of Corporate Governance on Banking Sector Performance in Nigeria', in International Journal of Economic Development Research and Investment, Vol. 2, Nos. 2.

[30]. Organization for Economic Co-operation and Development (OECD, 1999), OECD Principles of Corporate Governance, SG/CG 5.

[31]. Ogbechie, Chris, (2011), Corporate Governance Practices in the Nigerian Banking Industry, ICBE-RF Research Report No. 05/11, Dakar.

[32]. Okike, E.N.M. (2007), 'Corporate governance in Nigeria: The status quo', in Corporate Governance: An International Review, 15 (2):173-193.

[33]. Okpara, J.O. and Kabongo, J.D. (2010), "Corporate governance in a developing economy: a study of barriers and issues in Nigeria", Advanced Management Journal, Vol. 75, issue 3.

[34]. Olugbemi, B. (2011), 'Corporate Governance Practice and its impact on Nigerian Banking Industry', in the Lagos Banker, Vol.1 No.1, pg.42-46

[35]. Ifeanyi, D. N., Olagunju, A., Adeyanju, O. D. (2011), 'Corporate Governance and Bank Failure in Nigeria: Issues, Challenges and Opportunities', in Research Journal of Finance and Accounting, Vol. 2, No. 2.

[36]. Olagunju, A. and Oluwa, T.M.(2012), 'Corporate Governance and Performance of Money deposit banks in Nigeria', in International Trade and Academic Research Conference (ITARC), $7^{\text {th }}-8^{\text {th }}$ November, London, UK.

[37]. Sanusi, L. S. (2010), "The Nigerian Banking Industry: What went wrong and the way forward". Delivered at Annual Convocation Ceremony of Bayero University, Kano held on 3/1/2010 at Convocation Square.

[38]. Sanusi L. S. (2011a), "Banks in Nigeria and National Economic Development: A Critical Review". Being a keynote Address at the seminar on "Becoming an Economic Driver While Applying Banking Regulations", organized by the Canadian High Commission in Joint Collaboration with the Chartered Institute of Bankers of Nigeria (CIBN) and the Royal Bank of Canada (RBC) on March 7.

[39]. Sanusi, L. S. (2011b), "Banking Reforms and Economic Development in Nigeria", Being Paper Presented at a Retreat for Members of the Revenue Mobilization Allocation and Fiscal Commission on Thursday, 17th February, 2011 at Le Meridien Hotel, Uyo, Akwa Ibom State.

[40]. Sanusi, L. S. (2012), "Banking Reform and its Impact on the Nigerian Economy", CBN Journal of Applied Statistics, 2(2), pp. 115-122

[41]. Selltize, C. (1977), Research Methods in Social Relations, Methuen, London, pp. 335

[42]. Sulaiman, A. (2003), 'Corporate Governance and Organisational Performance', Issues in Corporate Governance, edited by Alo, $\mathrm{O}$.

[43]. Supangco, V. T. (2001a), The human resource management function and perception of organizational Performance, Philippine Management Review, 9, pp. 65-74.

[44]. Supangco, V.T. (2001b), 'Understanding HR's roles in selected firms in the Philippines', in Philippine Journal of Labour and Industrial Relations, 21(1 \& 2), pp. 41-50. 
[45]. Supangco, V. T. (2003). Management development in multinational and domestic organizations: The Philippine experience. Asia Pacific Management Review, 8(3): September.

[46]. Supangco, V. T. (2006), 'HR Involvement in Corporate Governance', in Philippines Management Review, vol.13, pp. 101-116

[47]. Vaughn, M. and Ryan, L.V. (2006), 'Corporate governance in South Africa: A bellwether for the continent?' Corporate Governance: An International Review, 14(5): 504-512

[48]. Wright, P.M. (2003) "Restoring Trust: The Role of HR in Corporate Governance”, Centre for Advanced Human Resource Studies, Working Paper Series 03-11, Cornell School of Industrial and Labour Relations, Ithaca, NY. pp. 120.

[49]. Yahaya, M. I. (1998) 'Corporate governance in Nigeria: Private sector perspective' in Yakasai G.A , (2001) 'Corporate governance in a Third World country with particular reference to Nigeria' Corporate Governance: An International Review, 9 (3): 239.

[50]. Yakasai G.A. (2001) 'Corporate governance in a Third World country with particular reference to Nigeria' Corporate Governance: An International Review, 9 (3): 239-240.

[51]. Youndt, M., Snell, S., Dean, J. \& Lepak, D. (1996), Human resource management, manufacturing strategy, and firm performance. Academy of Management Journal, 39(4), pp. 836-866. 